\title{
A 0 Fever Outbreak in the Netherlands: Consequences for Tissue Banking
}

\author{
Marja J. van Wijk ${ }^{a} \quad$ Boris M. Hogema ${ }^{b} \quad$ D. Willemijn Maas ${ }^{a} \quad$ Arlinke G. Bokhorst $^{a}$ \\ a BISLIFE Foundation, Leiden, \\ ${ }^{b}$ Sanquin Blood Supply Foundation, Departments of Blood-Borne Infections and Viral Diagnostics, Amsterdam, the Netherlands
}

\section{Keywords}

Q fever · Coxiella burnetii - Tissue transplantation

\section{Summary}

Background: Emerging infectious diseases can compromise the safety of tissues for transplantations. A recent outbreak of $\mathrm{Q}$ fever, a zoonosis caused by the bacterium Coxiella burnetii, in the Netherlands compelled the Dutch tissue banks to assess the risk of $Q$ fever transmission through tissue transplantation in order to maintain optimal safety. Methods: This article describes the systematic approach that was followed in the Netherlands. This approach included a review of the literature, a qualitative risk assessment, expert opinion gathering and investigations for specific strategies that can help to maintain the balance between tissue safety and availability. Results: This resulted in a specific donor selection policy and in development of further research to fill in gaps in knowledge about $\mathrm{Q}$ fever in tissue transplantation. Conclusion: The strategy described in this article may be useful for tissue bankers facing similar outbreaks of emerging infections or may be useful for development of future guidelines or assessment strategies for tissue banking.

\author{
Schlüsselwörter \\ Q-Fieber · Coxiella burnetii · Gewebetransplantation
}

\section{Zusammenfassung}

Aufstrebende Infektionskrankheiten können die Sicherheit von Geweben für Transplantationen kompromittieren. Ein aktueller Ausbruch von Q-Fieber in den Niederlanden, eine durch das Bakterium Coxiella burnetii verursachte Zoonose, hat die niederländischen Gewebebanken gezwungen, das Risiko einer Übertragung von Q-Fieber durch Gewebetransplantation zu beurteilen, um eine optimale Sicherheit zu gewährleisten. Methoden: Dieser Artikel beschreibt den systematischen Ansatz, welcher in den Niederlanden angewendet wurde. Dieser Ansatz beinhaltet eine Überprüfung der Literatur, eine qualitative Risikobewertung, die Sammlung von Expertenmeinungen sowie Untersuchungen spezifischer Strategien, welche helfen können, die Balance zwischen Gewebesicherheit und Verfügbarkeit aufrechtzuerhalten. Ergebnisse: Dies führte zu einer spezifischen Richtlinie zur Auswahl des Spenders sowie zur Entwicklung weiterer Forschungsansätze, um Lücken im Wissen über das Q-Fieber in der Gewebetransplantation zu füllen. Schlussfolgerung: Die Strategie, die in diesem Artikel beschrieben wird, kann nützlich sein für die Gewebebanken in Hinblick auf ähnliche Ausbrüche von Infektionskrankheiten sowie für die Entwicklung zukünftiger Richtlinien oder Assessment-Strategien.

\begin{tabular}{ll}
\hline KARGER & ๑ 2011 S. Karger GmbH, Freiburg \\
Fax +497614520714 & Accessible online at: \\
Information@Karger.de & www.karger.com/tmh \\
www.karger.com &
\end{tabular}




\section{Introduction}

In the Netherlands, $\mathrm{Q}$ fever has been a notifiable disease since 1978. Until 2006 the average annual number of reported cases was 17 [1]. In 2007 an increased number of 168 patient cases was reported in a specific region of the Netherlands [2]. In the next 2 years the number of reported patients increased up to 1,000 and 2,354 [3], which ranks the outbreak as the largest Q fever epidemic recorded to date.

Q fever is a zoonosis caused by infection with the bacterium Coxiella burnetii, which is present in a wide range of domesticated and wild animals. The human disease is mostly associated with goats and sheep. In those animals, Q fever can cause abortions, leading to the introduction of large amounts of $C$. burnetii in the environment. In the affected area of the Netherlands, there is a large density of dairy goats, of which a number tested positive for $\mathrm{Q}$ fever. In order to control the epidemic, the government took several measures. All infected pregnant goats and lambs were slaughtered in late 2009, and healthy animals were vaccinated. Furthermore, there was increased surveillance and a large campaign to increase awareness among the public. In 2010 and 2011, the number of reported cased decreased to 67 in the first half of 2011 [3]. Although the rate is still higher than before the start of the epidemic (possibly due to increased awareness), the worst of the epidemic seems to have passed.

The aim of tissue donation is to provide tissues with optimal safety to recipients who need them. With the Q fever outbreak in the Netherlands, the tissue establishments operating in the Netherlands were suddenly confronted with an emerging infectious disease that might compromise the safety for the recipients of tissue transplants. Therefore, the risk of $\mathrm{Q}$ fever transmission through tissue transplantation needed to be assessed in order to be able to determine which control measures might be useful or required.

There is no consensus on how to assess the risk of emerging infectious diseases on the safety of tissue transplantation.
Quantitative risk assessment models, as they are frequently used in the pharmaceutical industry and in hospitals [4], are difficult to use for tissue transplantation because it is hard to incorporate all aspects of tissue transplantation into a single model. It would be valuable to develop a quantitative risk assessment model specifically dedicated to assessing risks associated with emerging diseases for tissue transplantation, but thus far, to our knowledge, no such model has been developed although it is a subject of ongoing investigations especially in transfusion medicine [5]. Therefore, qualitative risk assessment is the best available instrument for this assessment. The European Center for Disease Control used a qualitative model to assess the risk of transmission of $\mathrm{Q}$ fever through blood transfusion [6]. In the current assessment a similar and systematic approach is taken to assess the risks for transmission of Q fever through tissue transplantation and to develop specific strategies, if they are considered necessary, that can help to maintain the balance between safety for tissue recipients and availability of tissues for transplantation.

The steps that were taken in this systematic approach are:

- A review of the literature in order to investigate various aspects of $\mathrm{Q}$ fever, including pathogenesis, transmission pathways, and clinical signs. Furthermore, it was investigated whether transmission of $\mathrm{Q}$ fever through tissue transplantation is theoretically possible and whether it has been reported in the literature.

- A risk assessment for the risk of transmission of $C$. burnetii through transplantation of the various tissues.

- Collection of expert opinions.

- An investigation of possible measures that could be taken to reduce the risk of transmission of $\mathrm{Q}$ fever through tissue transplantation and thus to optimize the safety of tissue transplant recipients. This included evaluation of testing possibilities, including possibilities for testing of post mortem obtained blood. Furthermore, background information was gathered for development of an optimal donor selection and testing strategy
Fig 1. Schematic presentation of the course of C. burnetii immune response and DNA during acute and chronic $\mathrm{Q}$ fever.

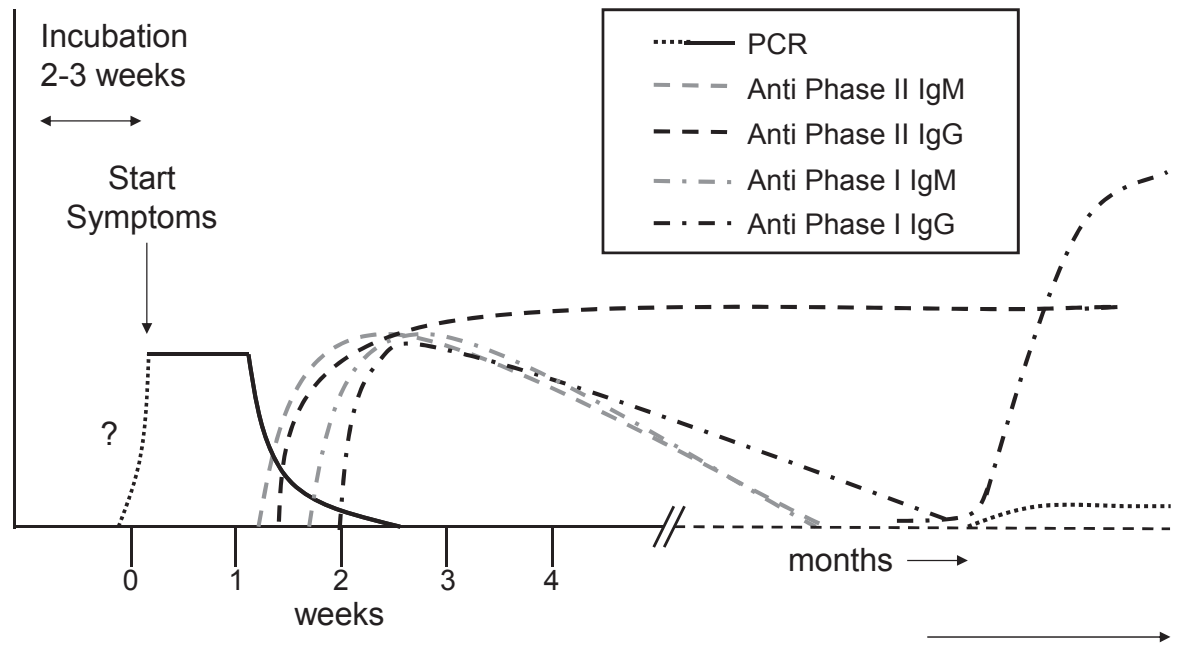

Acute $Q$ fever 


\section{Literature Review}

\section{Q Fever Background}

Q fever is a zoonosis caused by the obligate intracellular bacterium $C$. burnetii. Cattle, sheep, and goats are the primary animal reservoir, but the causative agent has also been noted in other animal species. Infected goats and sheep may abort, mainly in late pregnancy. The bacterium is shed in urine, feces, milk, and in especially high concentrations in placentas and birth fluids of infected animals. Spores are highly resistant to physical and chemical influences, including disinfectants, and can survive up to 40 months in the environment. Bacteria are transmitted to humans mainly through the aerosol route, but transmission through contaminated food and tick bites has been described [3]. In the Netherlands, there are no indications that ticks form a relevant reservoir, and even after the outbreaks the prevalence of $C$. burnetii in ticks remains low [7].

Most acute $C$. burnetii infections pass asymptomatic (approximately $60 \%$ ), but mild flu-like illness or severe disease with pneumonia, hepatitis, meningitis, meningo-encephalitis, pericarditis, myocarditis, rash, pancreatitis, orchitis, neuritis optica, or osteoarticular infection may occur after an incubation period of usually 1-3 weeks, depending on the inoculation dose [8]. It has been suggested that the clinical presentation may depend on the mode of transmission, with pneumonia developing after aerogenic transmission and granulomatous hepatitis after ingestion of high doses of bacteria [8]. After acute infection some patients develop a post-Q fever chronic fatigue syndrome. Current data suggest that $1.5-2 \%$ of patients develop chronic $\mathrm{Q}$ fever, most often persons with underlying cardiovascular disease, e.g. those with heart valve disease or aortic aneurysms, or immunocompromised individuals, such as pregnant women and organ transplant recipients $[6,8,9]$. Chronic $\mathrm{Q}$ fever most often presents as endocarditis or currently in the Netherlands also as vascular infections or colonization of vascular grafts [8-11]. Less frequently osteoarticular infections, chronic hepatitis and pericarditis occur. Estimates of the case fatality rate for chronic Q fever vary from 5 to $50 \%$, depending on clinical manifestations and treatment options [12].

C. burnetii infection can be detected in blood samples by PCR or serological testing. During acute Q fever, PCR tests on blood are usually positive from around the start of the clinical symptoms, and the presence of $C$. burnetii can also be demonstrated in urine and several other tissues. No data are available for the period prior to the symptomatic phase. However, 3/1,000 blood donations from donors from the highincidence area in the Netherlands in 2009 were PCR positive. Since blood is only donated by donors who appear healthy at the time of donation, this shows that $C$. burnetii DNA can be present during asymptomatic infection or prior to developing symptoms [13]. After seroconversion, which is usually 7-15 days after onset of clinical symptoms, DNA becomes undetectable and antibodies against phase 1 and phase 2 appear in the blood. These can be detected by immunofluorescence assays (IFAs), enzyme-linked immunosorbent assays (ELISA), or complement binding reaction (CBR) assays. In $90 \%$ of the cases antibodies are detectable by the $3 \mathrm{rd}$ week [8]. In figure 1 the 'normal' course of the various parameters that could be checked for are presented, as far as they are clear from the literature. IgM antibodies usually disappear months after the primary infection. IgG antibodies against phase 1 are usually low to absent months after the primary infection, but can reappear or persist in chronic infection when titers usually increase. IgG antibodies against phase II usually persist quite long after infection and may even persist lifelong [14]. Chronic Q fever is serologically often characterized by the presence of increased levels of anti-phase I antibodies $[8,15]$.

C. burnetii is an obligatory intracellular bacterium that is difficult to isolate and requires special techniques for culturing, which are not very sensitive [16]. Because of its high infectiousness and the fact that many laboratory-acquired cases have been described, culturing of these bacteria may only be done in biosafety level 3 laboratories [8]. Culture techniques using axenic medium, as they are usually employed in tissue banking do not detect presence of C. burnetii [8]. Therefore, the possibility of $\mathrm{Q}$ fever is usually assessed by serology or molecular diagnostics on blood or tissues.

After primary infection in symptomatic patients, there is usually spontaneous recovery within $1-2$ weeks. Acute Q fever can be treated with doxycyclin 2-3 weeks. For chronic Q fever long-term treatment is required, preferably with doxycyclin and hydroxychloroquine for a period of approximately 1.5 years [12].

\section{Q Fever Transmission through Tissue Transplantation}

In the literature, no $C$. burnetii transmission through tissue transplantation has been described. Single cases of likely transmission through blood transfusion [17] and possible transmission by bone marrow transplantation to an immunocompromised recipient [18] were reported. Transmission through transplantation (liver, thymus, and lymph nodes) in animals has been shown [19].

During the acute phase of infection, infectious $C$. burnetii is detectable in blood, bone marrow, urine, kidneys, placentas, and several other tissues [20,21]. After the acute phase, bacteria are usually not detectable in the blood, but it has been shown that they can persist a long time in monocytes, bone marrow, spleen, prostate, and liver, but may also persist in other tissues [22]. In one case C. burnetii DNA and antigen could be demonstrated in spleen and prostate of a patient 71 years after primary infection although there were no serological signs of chronic infection [23]. In patients with chronic $\mathrm{Q}$ fever, $C$. burnetii antigen has been shown in heart 
valves, vascular tissues and aneurysms, semen, lung, bone marrow, and liver [8, 14, 22-27]. In all tested heart valves of 5 endocarditis patients with chronic Q fever, C. burnetii DNA was detected [24]; in the aortic valve of one patient with chronic Q fever, infectious $C$. burnetii was present in a higher concentrations than in other tissues (spleen and lung) [28]. It is uncertain whether the demonstrable DNA after primary infection is associated with viable bacteria. Viable C. burnetii could not be detected in bone marrow samples long after primary infection although $C$. burnetii DNA was present in the bone marrow [24]. In contrast, viable bacteria have been cultured from bone marrow [14], cardiac valves [16], vascular grafts, and aneurysms [29] from patients with chronic Q fever.

\section{Risk Assessment for the Risk of Transmission of C. burnetii through Transplantation of Various Tissues}

Factors that could be relevant for determining the risk of transmission of $C$. burnetii through tissue transplantation were analyzed. The following factors are considered to be of importance: the incidence and prevalence of $\mathrm{Q}$ fever in the donor population, the type of tissue, whether pathogens can be present in the tissue, detectability of infection in donor and/or tissue, inactivation of $C$. burnetii during storage and/or processing, transmissibility, recipients, severity of the disease in recipients, and treatment options. Since the prevalence of $\mathrm{Q}$ fever in the donor population is probably equal for all tissue donors this factor was analyzed first. Subsequently, separate qualitative assessments were made for various tissues, because for each type of tissue there are major differences in tissue characteristics, storage and processing techniques, transmissibility and recipients.

\section{The Prevalence of $Q$ Fever in the Donor Population}

The seroprevalence of Q fever in the Dutch population prior to the large outbreaks was reported to be $2.4 \%$ [30]. In people with occupational hazard, e.g. farmers and veterinarians, the prevalence is higher [3]. In a recent study by the National Blood Services (Sanquin) during the Q fever outbreak in the Netherlands, the seroprevalence of previous infection among healthy blood donors from the highest incidence area was $12.2 \%$ at the end of 2009 . The seroprevalence of $C$. burnetii infection in the Dutch donor population shows large regional variations, making it difficult to estimate an average. The high seroprevalence of $12.2 \%$ was measured in a small area with 86,000 inhabitants. Although no data from large-scale studies performed after the outbreaks are available, a pilot study showed that the seroprevalence among blood donors outside the affected area is still low [13]. Thus, the seroprevalence can be estimated between 2.4 and $12.2 \%$, depending on the exposure level which mostly depends on residency. The prevalence of $C$. burnetii DNA in blood, a measure of acute Q fever, was $0.3 \%$ in the highest incidence area in the Netherlands in the summer of 2009 [13].

\section{Tissue-Specific Considerations}

\section{Cornea}

Corneas are avascular. Thus, during acute $\mathrm{Q}$ fever, when bacteria may be present in the blood, they are not expected to be present in the cornea. This is substantiated by the fact that during acute infection usually no ocular symptoms occur. Optic neuritis, uveitis, and one case of choroidal neovascularization have been described to occur in sporadic cases during the course of Q fever [31-34]. The presence of pathogens in the eye, however, has never been shown, and it is suspected that the ocular symptoms are due to inflammatory responses, not due to infective bacteria $[32,33]$.

The banking procedure of corneas usually includes microbiological assessment of the corneas or medium. However, detection of $C$. burnetii is not expected with the culture techniques that tissue banks usually employ. After a rinsing procedure and quality assessment, corneas are usually stored for a few days up to weeks in tissue culture medium. As mentioned before, it is not likely that $C$. burnetii is present in corneas. However, in case the tissue is infected, rinsing is not expected to affect the load as the bacteria are intracellular. Antibiotics present in the storage medium are not expected to affect $C$. burnetii as this bacterium requires a specific antibiotic regime [35] with extended exposure. Since $C$. burnetii is quite resistant to chemical and environmental factors, it is not expected that inactivation during processing or storage occurs.

C. burnetii is a virulent species. Inhalation of one or few bacteria has been shown to be sufficient for infection [36], and although other routes of infection are more efficient, intraperitoneal injection or transplantation of tissues causes infections in mice and guinea pigs $[19,37,38]$. Thus, it can be expected, at least theoretically, that presence of viable bacteria in a transplanted cornea could lead to infection of recipients. Although sometimes local immunosuppressants are given after cornea transplantation, cornea recipients are usually immunocompetent. Thus, they do not have an increased risk of a complicated disease course with chronic Q fever. Treatment of detected disease could be done with the current advised regime and is expected to be successful, similar to treatment in the general population.

\section{Skin}

Skin is well vascularized and contains monocytes [39]. There are indications that $C$. burnetii DNA can persist in blood mononuclear cells in patients with post-Q fever chronic 
fatigue syndrome [22]. Therefore, it can be argued that bacteria may be present in donor skin for transplantation. This hypothesis is strengthened by the maculopapular or diffuse punctiform pruritic rash that have been described to occur in acute $Q$ fever in $5-21 \%$ of the patients [8, 40-42] and by the culture of $C$. burnetii in a patient who had skin symptoms from a skin biopsy as well as from the blood [16].

During the processing and storage process at the bank, microbiological assessment of the cutaneous tissues is done. Since this concerns axenic cultures, it is not expected to detect C. burnetii. Skin for transplantation can be stored using different methods; usually glycerol or cryopreservant is used. The effect of glycerol on C. burnetii viability has not been investigated. However, some spore-forming bacteria are not affected by glycerol $[43,44]$ and, thus, C. burnetii, which also has a form of sporulation, may not be affected by storage in glycerol. On the other hand, by treatment of donor skin with glycerol, cells are rendered non-viable [38, 45]; thus intracellular $C$. burnetii may be rendered harmless. Cryopreservation of skin is not expected to have an effect on the viability of C. burnetii in cutaneous tissues. Irradiation of cryopreserved skin has been shown to have a sterilizing effect on donor skin although the effect of irradiation on $C$. burnetii has not been tested specifically [46]. Thus, during processing and storage of cutaneous tissues, $C$. burnetii infection would probably not be detected, and whether it will be affected by it is insufficiently known. Because of the virulence of $C$. burnetii [36], presence of viable bacteria in cutaneous tissue, can be expected to be transmitted to recipients. However, most skin grafts are not used as implantate, but as a temporary wound dressing, thereby decreasing the chance of disease transmission. Recipients of cutaneous transplants are usually immunocompetent although due to extensive burns they may become relatively immunodeficient and thus may become increasingly susceptible for a complicated disease course. Treatment of transmitted disease could be done with the treatment protocol used in the general population, and a similar outcome could be expected.

\section{Heart Valves and Vascular Tissue}

Cardiovascular tissues are one of the target tissues of $\mathrm{Q}$ fever. During acute $\mathrm{Q}$ fever, pericarditis and myocarditis occur in $0.5-1 \%$ and $1 \%$ of patients, respectively [8], while in chronic Q fever endocarditis or, as currently in the Netherlands, also vascular infections or colonization of vascular grafts are the major clinical presentations [8-11, 25, 47]. Thus, it is likely that during the acute phase of the infection as well as in chronic $\mathrm{Q}$ fever $C$. burnetii is present in cardiovascular tissues as they are used for transplantation. The presence of $C$. burnetii in heart valves and vascular tissues and aneurysms has been shown in patients with chronic $\mathrm{Q}$ fever [8, 24, 25, 28, 48], and viable bacteria have been cultured in patients with chronic Q fever from cardiac valves [16], vascular grafts, and aneurysms [29].
Q fever endocarditis usually involves the aortic and the mitral valve or prosthetic valves. The typical vegetation is small, and in only $12 \%$ of patients the vegetation is visible with ultrasound. Thus, these case of vegetation are probably difficult to recognize at assessment of the valves for suitability for transplantation by the bank technicians. If after morphological assessment cardiovascular grafts are approved for further processing, microbiological assessment is done. However, since axenic cultures are used, these are not expected to detect $C$. burnetii infection. Before release of cardiovascular products for transplantation, histopathological examination of the remnants of the heart is usually performed [49]. However, since the histological findings in $Q$ fever endocarditis are nonspecific and bacterial vegetations are small or nonexistent, abnormalities may be missed at sampling or at examination [8].

Heart valves and other cardiovascular transplants are usually stored by cryopreservation. Antibiotic decontamination is performed before cryopreservation of the valves [50]. However, the used incubation time is usually short (6-24 h), and the most common antibiotic regimes are not expected to have a bactericidal effect on $C$. burnetii in such a short period. Cryopreservation is not expected to have an effect on the viability of $C$. burnetii. Irradiation is not commonly used for sterilization of heart valves for transplantation because of its potential damaging effect [51]. Decellularization of grafts, as is currently being investigated, may, by compromising cell viability, also affect $C$. burnetii viability [52].

If infected regular valves or vascular tissues are transplanted, transmission of infection seems likely, in particular if the transplanted tissue contains bacterial vegetations. Recipients of homografts are by definition at high risk for chronic Q fever as they have valve disease. Mortality from Q fever endocarditis is less than $10 \%$ when the appropriate antibiotic regime is administered, but treatment is long ( $>1.5$ years), and there is a high relapse rate $(>50 \%)$ after withdrawal of the antibiotics [8]. Furthermore, surgical removal of the infected valve is no guarantee for cure [8], instead it puts recipients at increased risk because of the need for additional major surgery.

\section{Musculoskeletal Tissues}

Osteoarticular infection has been reported to occur in $C$. burnetii infection. It mainly presents as osteomyelitis or osteoarthritis and occurs especially in children suffering from coxitis or spondylodiscitis or in adults who are immunocompromised or have a joint prosthesis [8]. During the acute phase of infection, infectious viable $C$. burnetii has been detected in bone marrow [16, 20, 21]. After acute Q fever, C. burnetii DNA can still be detected in bone marrow, but culturing $C$. burnetii was not possible [24]. In patients with chronic Q fever, C. burnetii DNA and antigen have been shown in bone marrow, and viable $C$. burnetii has been isolated $[8,14,22,24]$. Cultures taken of bones or tendons re- 
trieved are not expected to be effective in showing $C$. burnetii infection as axenic culturing techniques are used in tissue banking. If fresh frozen or freeze dried grafts are the intended products of cryopreservation, there is no inactivating effect to be expected of processing. However, there are several possibilities for processing of musculoskeletal tissues that are expected to affect $C$. burnetii viability. Sterilization by irradiation, peracetic acid treatment or other terminal sterilization, or decellularization techniques may inactivate C. burnetii. Peracetic acid treatment has been demonstrated to be effective for several spore-forming bacteria [53] and may therefore also affect $C$. burnetii viability.

If viable bacteria are present in bone, bone marrow, or tendons, they could be transmissible to recipients. Recipients of bone products are mainly immunocompetent individuals although there are oncologic indications for bone transplantations which may involve recipients with a suboptimal immune status. As osteoarticular infections occur during chronic Q fever, it seems plausible that recipients of musculoskeletal grafts may develop chronic $\mathrm{Q}$ fever. This would require extended antibiotic treatment and might also require surgical treatment, thus putting recipients of infected grafts at increased risk.

\section{Expert Opinion}

During the Q fever outbreak in the Netherlands the National Institute for Public Health and the Environment (RIVM) was coordinating the information gathering. The epidemic was focused in the southern part of the Netherlands. In this area, major risk factors were occupational hazards, especially in farmers and veterinarians as well as in their families. In addition, persons living within a $5 \mathrm{~km}$ radius from a farm with an increased abortion rate due to $\mathrm{Q}$ fever are considered to be at risk [54]. The number of reported $\mathrm{Q}$ fever cases was monitored closely and made publicly available. Furthermore, consensus group meetings were held in which experts from various fields (microbiologists, clinicians, and public health specialists) discussed optimal diagnostic algorithms for $\mathrm{Q}$ fever [55]. Because of their expertise they also advised the tissue donation field to investigate possibilities for additional testing. The Food and Consumer Product Safety Authority (VWA) reported the postal codes of farms with known $C$. burnetii infection (as determined by tank milk monitoring or increased abortion rates). Together with the Department of Infection Diagnostics Services of the National Blood Service (Sanquin), which performs the blood screening tests for tissue donors in the Netherlands, possibilities were investigated for diagnostic testing of tissue donors, including validation of ELISA tests for blood obtained post mortem. An advice of the Dutch Health Council on how to handle the risk of $Q$ fever in tissues and cells for transplantation is expected in the second half of 2011.

\section{Additional Measures to Prevent Q Fever Transmission through Tissue Transplantation in the Netherlands}

\section{Donor Selection Measures}

During the progression of the epidemic in the Netherlands, additional control measures were implemented in the Netherlands to reduce the risk of transmitting $C$. burnetii through tissue transplantation. This included exclusion of donors with occupational hazard (especially farmers and veterinarians and their families) and increased information gathering and additional risk assessment of donors with increased risk of acute or chronic Q fever, based on geographical risk factors (e.g. living within a $5 \mathrm{~km}$ radius of a (previously) infected farm or in an area with a high prevalence of $\mathrm{Q}$ fever cases) and on clinical presentation (e.g. pneumonia, ruptured aneurysm) and medical history. Furthermore, the possibility for serological testing was investigated as well as processing strategies that can render the bacteria harmless.

\section{Blood Testing}

Based on the results of the risk assessment and the advice of the expert group, assembled by the RIVM, a pilot study was performed to investigate the possibility of serological testing for infection with $C$. burnetii. Figure 1 shows potential targets for detection of $C$. burnetii infection in blood. The earliest possible detection of infection with $C$. burnetii can be done by PCR testing as mentioned previously. Disadvantage of PCR testing on blood obtained post mortem is that DNA is likely to be unstable in post mortem blood and can thereby cause false-negativity. Furthermore, not all chronic patients are PCR-positive and, thus, it is not a good marker for chronic infection. As presented earlier, 7-15 days after the start of the symptoms serologic conversion occurs, with various $\operatorname{IgM}$ and $\operatorname{IgG}$ antibodies against phase I and II of $C$. burnetii appearing [56]. Serologic testing has the advantage that also past infections with $C$. burnetii can be detected. IgM antibody testing could detect recent infections (months old), but IgG phase II antibodies seems to be the marker of choice to test for if older infections also need to be detected.

There are several commercially available, CE marked test kits available that use different detection techniques to detect IgG phase II antibodies against $C$. burnetii. IFA tests are by many considered the standard test of choice $[8,55]$. However, IFAs are not very practical for screening purposes; they are more prone to interobserver variability and tend to give more false-positive results than ELISAs when used on post mortem blood. CBR and especially ELISA tests are frequently used on post mortem blood without major problems. IgM antibody screening with ELISA (Serion/Virion, Clindia Benelux, Leusden, the Netherlands) resulted in a high false- 
positivity rate in blood samples of living patients [55] and can only detect recent infections; therefore, a pilot study was done to investigate the usability of IgG phase I and II testing on post mortem blood. For this test 49 consecutive donors were tested for the presence of IgG phase I or II with a CE marked ELISA (Serion/Virion). Furthermore, spiking experiments were done, in which 20 donor samples obtained post mortem were spiked with serum from phase I and II IgG-positive samples and then tested. In the pilot study 49 donors were included with a mean age of $62.7 \pm 13.1$ years. $51 \%$ of the donors were males and the donated tissues were corneas $(77.6 \%)$, skin $(24.5 \%)$, heart valves $(10.2 \%)$, and musculoskeletal tissues $(10.2 \%)$. Eight of the donors lived within a $5 \mathrm{~km}$ radius of an infected farm. One donor had a previous pneumonia, which could have been $\mathrm{Q}$ fever-related. 48 of the 49 donors tested phase I and II IgG-negative, while 1 donor tested phase II IgG-positive and phase I IgG borderline positive. This could be confirmed with a commercial IFA test for both phase I and II IgG. PCR testing for the presence of C. burnetii DNA in the heart and heart valves was negative. Thus, this donor, who lived within a $5 \mathrm{~km}$ radius of an infected farm, might have gone through a past infection with C. burnetii.

At spiking experiments phase I and II IgG could be detected normally in all 20 spiked samples; so there was no significant signal inhibition in the post mortem blood samples.

Thus, in this limited validation the tested phase I and II IgG ELISA tests displayed good (expected) sensitivity and specificity for detection of past $C$. burnetii infection, and it was concluded that phase II IgG ELISA is usable for detection of past $C$. burnetii infection in blood obtained post mortem. Based on the results of this pilot study, a larger study was designed to investigate the use of serological testing for past infection with $C$. burnetii in tissue donors and to gather additional information about the prevalence of past $C$. burnetii infection in Dutch tissue donors and their specific epidemiological and clinical risk factors.

\section{Conclusion}

Emerging infectious diseases can compromise the safety of tissues for transplantations. As they often appear unexpected and demand immediate action, it is important that risk assessment strategies of emerging infectious diseases are available for tissue transplantation. In the literature no consensus exists on how to assess the risk of emerging infectious diseases. In blood banking strategies are currently being developed that may also be useful for tissue banking. Since there are many different types of tissues for transplantation that all have specific assessment, processing and storage procedures, and recipients with different risk profiles, risk assessment can be quite elaborate and complicated. Quantitative risk assessment with the systems, as they are often used in health care and the pharmaceutical industry, are difficult to apply to tissues for transplantation since all relevant factors often do not fit in one model.

This article describes the systematic approach that was followed in the Netherlands when Dutch tissue banks were confronted with a large outbreak of Q fever. This approach included a literature review, a qualitative risk assessment, expert opinion gathering, and investigations for specific strategies that can help to maintain the balance between safety for tissue recipients and availability of tissues for transplantation. Currently, the data of a larger study, which investigates the possibility of serological testing of tissue donors for previous infection with $C$. burnetii, are being analyzed. These data may provide additional information on how to handle future outbreaks of Q fever. Furthermore, the strategy described in this article may be useful for tissue bankers facing similar outbreaks of emerging infections or for the development of future guidelines or assessment strategies for tissue banking.

\section{Disclosure Statement}

The authors declared no conflict of interest.

\section{References}

1 Schimmer B, Dijkstra F, Vellema P, Schneeberger PM, Hackert V, ter Schegget R, Wijkmans C, van Duynhoven Y, van der Hoek W Sustained intensive transmission of $\mathrm{Q}$ fever in the south of the Netherlands, 2009. Euro Surveil 2009;14(19):19210. http://www.eurosurveillance.org/ images/dynamic/EE/V14N19/art19210.pdf.

2 Karagiannis I, Morroy G, Rietveld A, Horrevorts AM, Hamans M, Francken P, Schimmer B: A Q fever outbreak in the Netherlands: a preliminary report. Euro Surveill 2007;12(32):3247. www.eurosurveillance.org/ViewArticle. aspx? ArticleId $=3247$.

3 RIVM (National Institute for Public Health and the Environment of The Netherlands): $\mathrm{Q}$ fever, www.rivm.nl/Onderwerpen/Ziekten_ Aandoeningen $/ Q / Q \_$koorts, accessed August 2011.
4 European Commission. Eudralex: The Rules Governing Medicinal Products in the European Union. Volume 4. EU Guidelines to Good Manufacturing Practice Medicinal Products for Human and Veterinary Use. Annex 20 Quality Risk Management 2008, http://ec.europa.eu/health/files/ eudralex/vol-4/pdfs-en/2008_02_12_gmp_annex20_ en.pdf, accessed August 2011.

5 Atreya C, Nakhasi H, Mied P, Epstein J, Hughes J, Gwinn M, Kleinman S, Dodd R, Stramer S, Walderhaug M, Ganz P, Goodrich R, Tibbetts C, Asher D: FDA workshop on emerging infectious diseases: evaluating emerging infectious diseases (EIDs) for transfusion safety. Transfusion 2011; 51:1855-1871.
6 European Center for Disease Control: Technical Report: Risk Assessment on Q Fever. http://ecdc. europa.eu/en/publications/Publications/1005_TER_ Risk_Assessment_Qfever.pdf, accessed August 2011. Doi: 10.2900/28860.

7 Sprong H, Tijsse-Klasen E, Langelaar M, De Bruin A, Fonville M, Gassner F, Takken F, Van Wieren S, Nijhof A, Jongejan F, Maassen CBM, Scholte EJ, Hovius JW, Emil Hovius K, Špitalská E, Van Duynhoven YT: Prevalence of Coxiella burnetii in Ticks after a large outbreak of Q fever. Zoonosis Public Health 2011. DOI:10.1111/j.18632378.2011,01421.x.

8 Maurin M, Raoult D: Q fever. Clin Microbiol Rev 1999;12:518-553. 
9 Million M, Thuny F, Richet H, Raoult D: Longterm outcome of Q fever endocarditis: a 26-year personal survey. Lancet Infect Dis 2010;10:527-535.

10 Brouqui P, Raoult D: Endocarditis due to rare and fastidious bacteria. Clin Microbiol Rev 2001;14: 177-207.

11 Raoult D, Tissot-Dupont H, Foucault C, Gouvernet J, Fournier PE, Bernit E, Stein A, Nesri M, Harle JR, Weiller PJ: Q fever 1985-1998. Clinical and epidemiologic features of 1,383 infections. Medicine (Baltimore) 2000;79:109-123.

12 Raoult D, Houpikian P, Tissot Dupont H, Riss JM, Arditi-Djiane J, Brouqui P: Treatment of Q fever endocarditis: comparison of 2 regimens containing doxycycline and ofloxacin or hydroxychloroquine. Arch Intern Med 1999;159:167-173.

13 Hogema BM, Slot E, Molier M, Schneeberger PM, Hermans MH, Van Hannen EJ, Van der Hoek W, Cuijpers HT, Zaaijer HL: Coxiella burnetii infection among blood donors during the 2009 Q-fever outbreak in the Netherlands. Transfusion 2011. doi:10.1111/j.1537-2995.2011.03250.x

${ }_{14}$ Peacock MG, Philip RN, Williams JC, Faulkner RS: Serological evaluation of Q fever in humans: enhanced phase I titers of immunoglobulins $G$ and A are diagnostic for $\mathrm{Q}$ fever endocarditis. Infect Immun 1983;41:1089-1098.

15 Tissot Dupont H, Thirion X, Raoult D: Q fever serology: cutoff determination for microimmunofluorescence. Clin Diagn Lab Immunol 1994;1:189-196.

16 Raoult D, Vestris G, Enea M: Isolation of 16 strains of Coxiella burnetii from patients by using a sensitive centrifugation cell culture system and establishment of the strains in HEL cells. J Clin Microbiol 1990;28:2482-2484.

17 Raoult D, Marrie T: Q fever. Clin Infect Dis 1995; 20:489-495.

18 Kanfer E, Farrag N, Price C, MacDonald D, Coleman J, Barrett AJ: Q fever following bone marrow transplantation. Bone Marrow Transplant 1988;3: 165-166.

19 Criley JM, Carty AJ, Besch-Williford CL, Franklin CL: Coxiella burnetii infection in C.B-17 scidbg mice xenotransplanted with fetal bovine tissue. Comp Med 2001:51:357-360.

20 Derrick EH: The course of infection with Coxiella burnetii. Med J Aust 1973;1:1051-1057.

-21 Raoult D, Stein A: Q fever during pregnancy - a risk for women, fetuses, and obstetricians. N Engl J Med 1994;330:371 (Letter).

22 Harris RJ, Storm PA, Lloyd A, Arens M, Marmion BP: Long-term persistence of Coxiella burnetii in the host after primary Q fever. Epidemiol Infect 2000;124:543-549.

23 Marmion BP, Sukocheva O, Storm PA, Lockhart M, Turra M, Kok T, Ayres J, Routledge H, Graves S: Q fever: persistence of antigenic non-viable cell residues of Coxiella burnetii in the host-implications for post Q fever infection fatigue syndrome and other chronic sequelae. QJM 2009;102:673-684.

24 Marmion BP, Storm PA, Ayres JG, Semendric L, Mathews L, Winslow W, Turra M, Harris RJ: Long-term persistence of Coxiella burnetii after acute primary Q fever. QJM 2005;98:7-20.
5 Wever PC, Arts C, Groot CAR, Lestrade PJ, Koning $\mathrm{OHJ}$, Renders NHM: Screening for chronic Q fever in symptomatic patients with an aortic aneurysm or prosthesis. Ned Tijdschr Geneeskd 2010;154:A2122.

26 Milazzo A, Hall R, Storm PA, Harris RJ, Winslow W, Marmion BP: Sexually transmitted Q fever. Clin Infect Dis 2001;33:399-402.

27 Whittick JW: Necropsy findings in a case of Q fever in Britain. Br Med J 1950;1:979-980.

28 Andrews PS, Marmion BP: Chronic Q fever. Morbid anatomical and bacteriological findings in a patient with endocarditis. Br Med J 1959;2:983-988.

29 Micoud M, Brion JP, Boulard JC, Magne JL, Gratacap B, Stahl JP, Farah I, Raoult D: Infection of aortic aneurysm with Coxiella burnetii. Lancet 1991;338:584.

30 Schimmer B, Notermans DW, Harms MG, Reimerink JH, Bakker J, Schneeberger P, Mollema L, Teunis P, Van Pelt W, Van Duynhoven Y: Low seroprevalence of Q fever in the Netherlands prior to a series of large outbreaks. Epidemiol Infect 2011;16:1-9.

31 Schuil J, Richardus JH, Baarsma GS, Schaap GJ: Q fever as a possible cause of bilateral optic neuritis. Br J Ophthalmol 1985;69:580-583.

32 Million M, Halfon J, Le Lez ML, Drancourt M, Raoult D: Relapsing uveitis and optic neuritis due to chronic Q fever. Br J Ophthalmol 2011;95:1026.

33 Matonti F, Conrath J, Bodaghi B, Le Hoang P, Raoult D, Drancourt M: Uveitis in the course of Qfever. Clin Microbiol Infect 2009;2:176-177.

34 Ruiz-Moreno JM: Choroidal neovascularization in the course of Q fever. Retina 1997;17:553-555.

35 Raoult D, Torres H, Drancourt M: Shell-vial assay: evaluation of a new technique for determining antibiotic susceptibility, tested in 13 isolates of Coxiella burnetii. Antimicrob Agents Chemother 1991; 35:2070-2077.

36 Stein A, Louveau C, Lepidi H, Ricci F, Baylac P, Davoust B, Raoult D: Q fever pneumonia: virulence of Coxiella burnetii pathovars in a murine model of aerosol infection. Infect Immun 2005;73: 2469-2477.

37 Scott GH, Burger GT, Kishimoto RT: Experimental Coxiella burnetii infection of guinea pigs and mice. Lab Anim Sci 1978;28:673-675.

38 Tamrakar SB, Haluska A, Haas CN, Bartrand TA: Dose-response model of Coxiella burnetii (Q fever). Risk Anal 2011:31:120-128.

\$3 Richters CD, Hoekstra MJ, du Pont JS, Kreis RW, Kamperdijk EW: Immunology of skin transplantation. Clin Dermatol 2005;23:338-342.

40 Dupuis G, Peter O, Pedroni D, Petite J: Clinical aspects observed during an epidemic of 415 cases of $\mathrm{Q}$ fever. Schweiz Med Wochenschr 1985;115:814-818.

41 Spelman DW: Q fever: a study of 111 consecutive cases. Med J Aust 1982;1:547-553.
42 Tissot Dupont H, Raoult D, Brouqui P, Jannbon F, Peyramond D, Weiller PJ, Chicheportiche C, Nezri M, Poitier R: Epidemiological features and clinical presentation of acute $\mathrm{Q}$ fever in hospitalized patients - 323 French cases. Am J Med 1992;93:427-434.

43 Verbeken G, Verween G, De Vos D, Pascual B, De Corte P, Richters C, De Coninck A, Roseeuw D, Ectors N, Rose T, Jennes S, Pirnay JP: Glycerol treatment as recovery procedure for cryopreserved human skin allografts positive for bacteria and fungi. Cell Tissue Bank 2011;DOI: 10.1007/s10561011-9244-6.

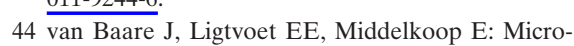
biological evaluation of glycerolized cadaveric donor skin. Transplantation 1998;65:966-970

45 Richters CD, Hoekstra MJ, van Baare J, du Pont JS, Kamperdijk EWA: Morphology of glycerol-preserved human cadaver skin. Burns 1996;22:113-116.

46 P. Rooney, M. Eagle, P. Hogg, R. Lomas, J. Kearney: Sterilisation of skin allograft with gamma irradiation. Burns 2008;34:664-673.

47 Khavkin T: Coxiella burnetii infection in prosthetic devices. Rev Infect Dis 1989;11:835.

48 Brouqui P, Dumler JS, Raoult D: immunohistologic demonstration of Coxiella burnetii in the valves of patients with Q fever endocarditis. Am J Med 1994;97:451-458.

49 Mackey-Bojack S, Roe S, Titus JL: Review of pathologic findings in remnant hearts following valve donation. J Forensic Sci 2007;52:692-697.

50 Germain M, Thibault L, Jacques A, Tremblay J, Bourgeois R: Heart valve allograft decontamination with antibiotics: impact of the temperature of incubation on efficacy. Cell Tissue Bank 2010;11: 197-204.

51 Campalani G, Chalmers JAC, Weaver EJM: Aortic valve replacement with frozen irradiated homografts. An 18-year experience. Eur J Cardiothorac Surg 1989;3:558-561.

52 Akhyari P, Minol P, Assmann A, Barth M, Kamiya $\mathrm{H}$, Lichtenberg $\mathrm{A}$ : Tissue engineering of heart valves. Chirurg 2011;82:311-318.

53 Leaper S: Synergistic killing of spores of Bacillus subtilis by virus safety of avital bone tissue transplants: evaluation of peracetic acid and alcohol. J Food Technol 1984;19:355-360.

54 Schimmer B, Ter Schegget R, Wegdam M, Züchner L, de Bruin A, Schneeberger PM, Veenstra T, Vellema P, van der Hoek W: The use of a geographic information system to identify a dairy goat farm as the most likely source of an urban Q-fever outbreak. BMC Infect Dis 2010;16:69.

55 Wegdam-Blans MC, Nabuurs-Franssen MN, Horrevorts AM, Peeters MF, Schneeberger PM, Bijlmer HA: Laboratory diagnosis of acute $\mathrm{Q}$ fever. Ned Tijdschr Geneeskd 2010;154:A2388.

56 Schneeberger PM, Hermans MH, van Hannen EJ, Schellekens JJ, Leenders AC, Wever PC: Realtime PCR with serum samples is indispensable for early diagnosis of acute Q fever. Clin Vaccine Immunol 2010;17:286-290. 